\title{
INCREASED SUSCEPTIBILITY OF RABBITS TO INTRAVENOUS CHALLENGE WITH MYCOBACTERIUM AVIUM AFTER MILD HEPATITIS PRODUCED BY CARBON TETRACHLORIDE
}

\author{
N. B. Singh, I. S. Mathur, H. P. Gupta, A. Srivastava and S. K. Gupta \\ Division of Microbiology, Central Drug Research Institute, Lucknow-226001, India
}

\section{Plate XVI}

MiLD liver damage and cirrhosis are common sequelae of alcoholism (Kumar and Desai, 1976), malnutrition (Gothoskar, 1931), metabolic defects (Dhatt, Gupta and Saini, 1968), toxic agents (Jelliffe, Bras and Mukherji, 1957), intestinal parasitism (Banerji et al., 1968) and viral infections (Dayal et al., 1968). Persons with mild hepatitis may be exposed to mycobacterial infection. No correlation seems to have been established between liver damage and mycobacterial infection, although hepatic damage in chronic pulmonary tuberculosis has been reported (Ban, 1955). The present studies were undertaken to investigate the effect of liver damage caused by carbon tetrachloride $\left(\mathrm{CCl}_{4}\right)$ on the progress of Mycobacterium avium infection in the rabbit.

\section{MATERIALS AND METHODS}

Animals used. Albino rabbits, bred in this institute and weighing $1-2 \mathrm{~kg}$, were each kept in a separate cage and fed on a standard diet with water ad libitum.

Bacterial strains. M. avium strain Kirschberg (TMC801), was obtained from the National Institute of Health, Tokyo, Japan and grown and maintained on Löwenstein-Jensen medium. A 14-day-old growth was homogenised in $0.07 \mathrm{M}$ sodium phosphate $(p \mathrm{H} 8.7)$ at two concentrations: 1.0 and $0.4 \mathrm{mg}$ (wet weight) $/ \mathrm{ml}$.

Administration of $\mathrm{CCl}_{4}$. Rabbits received a total of 23 bi-weekly subcutaneous injections each of $0.05 \mathrm{ml}^{\circ} \mathrm{CCl}_{4}$ (British Drug Houses).

Challenge with $M$. avium. Groups of $\mathrm{CCl}_{4}$-treated and untreated control animals received intravenous injections of suspensions of $M$. avium 3 days after the last dose of $\mathrm{CCl}_{4}$ in the treated group. In experiment no. $1,16 \mathrm{CCl}_{4}$-treated and nine control rabbits each received $0.5 \mathrm{mg}$ of mycobacteria, and in experiment no. 2, nine treated and nine control animals each received 0.2 mg. All animals were observed for loss of body weight, and survival-times were recorded.

Examination at necropsy. Visceral organs of animals that died or were killed were inspected, weighed and sampled aseptically. Smears stained by the Ziehl-Neelsen (ZN) method were examined microscopically for acid-fast bacilli (AFB). Portions of the organs were fixed in $10 \%$ formal saline (a 1 in 10 dilution of $40 \%$ aqueous formaldehyde in physiological saline); sections were cut and stained by the haematoxylin-eosin and $\mathrm{ZN}$ methods. Viable counts of mycobacteria in visceral tissue were made by spreading appropriate saline dilutions of homogenates on slopes of Lowenstein-Jensen medium; results were expressed as colony-forming units (c.f.u.)/g of tissue.

\section{RESULTS}

In a preliminary experiment, four rabbits were killed 3 days after the last $\mathrm{CCl}_{4}$ injection. The liver tissue in all cases was oedematous and had a finely granular appearance. Histopathologically there was evidence of degenerative changes; islets of fibrous tissue surrounded and were compressing the liver cells, simulating Cameron grade-I hepatitis (Cameron and Karunaratne, 1936). 


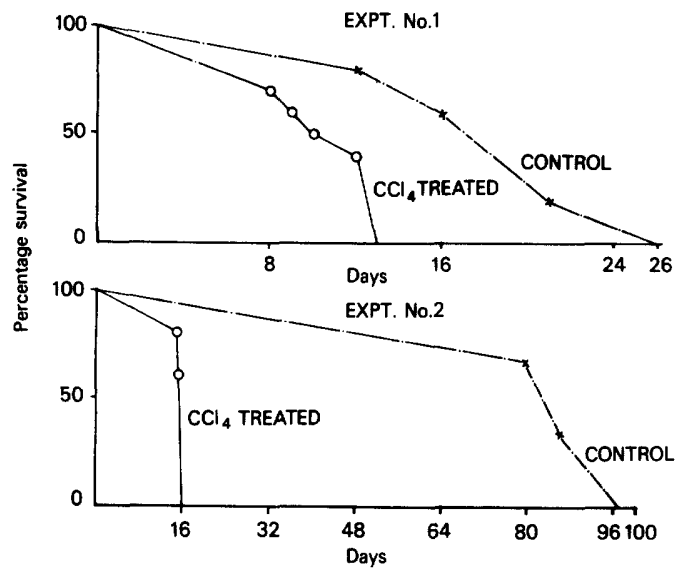

FiG. 1.- Survival pattern of rabbits that had been pre-treated with carbon tetrachloride, and of rabbits not so treated, after infection with Mycobacterium avium; experiment no. 1 , infecting dose $0.5 \mathrm{mg}$, and experiment no. 2 , infecting dose $0.2 \mathrm{mg}$ (wet weight) of bacteria.

Experiment no. 1. The $\mathrm{CCl}_{4}$-treated rabbits that had received $0.5 \mathrm{mg}$ of mycobacteria became ill and died earlier than did the control animals (fig. 1). The mean survival time (MST) for the treated group was 10.6 \pm 0.5 days and for the control group 19.2 \pm 2.3 days.

When $50 \%$ of the animals in the $\mathrm{CCl}_{4}$ group had died (day 12), two animals from each group were killed. At necropsy, the two $\mathrm{CCl}_{4}$-treated rabbits showed miliary nodules in the lung, and the spleen was grossly enlarged with sago-grain-sized nodules. The liver tissue showed areas of congestion, islets of epithelioid cells were present between the normal cells, and large clumps of AFB were seen (fig. 2). Epithelioid cells with enormous numbers of AFB were present in the lung lesions. The splenic tissue revealed loss of follicular pattern, occasional giant cells, collections of epithelioid cells (fig. 3), and large clumps of AFB (fig. 4).

In the control group these changes were less severe, although minimal lesions were present. Histologically the cell reaction was predominantly of macrophages with only a few epithelioid cells. There were fewer AFB in the tissues in comparison with the $\mathrm{CCl}_{4}$ group.

The impression smears of all the organs of rabbits killed on day 12 were positive for AFB in

\section{TABLE I}

Body and organ weights at the time of death, and mean survival times, of rabbits infected with $M y c o b a c t e r i u m$ avium* which had (1) previously been treated with carbon tetrachloride $\left(\mathrm{CCl}_{4}\right) \dagger$ and (2) not been so treated; (3) body and organ weights of uninfected and untreated rabbits

\begin{tabular}{|c|c|c|c|c|c|c|c|}
\hline \multirow[b]{2}{*}{$\begin{array}{c}\text { Experimental } \\
\text { group (number } \\
\text { of rabbits) }\end{array}$} & \multirow{2}{*}{$\begin{array}{l}\text { Weight at } \\
\text { time of } \\
\text { infection } \\
(\mathrm{kg})\end{array}$} & \multirow{2}{*}{$\begin{array}{c}\text { Weight at } \\
\text { death } \\
(\mathrm{kg})\end{array}$} & \multicolumn{4}{|c|}{ Weight (g) of } & \multirow{2}{*}{$\begin{array}{l}\text { Mean survival } \\
\text { time (days) }\end{array}$} \\
\hline & & & lungs & liver & spleen & kidney & \\
\hline \multirow{3}{*}{$\begin{array}{l}\text { 1. } \mathrm{CCl}_{4} \text { treated; } \\
\text { infected (7) } \\
\text { 2. Untreated; } \\
\text { infected (7) } \\
\text { 3. Untreated; } \\
\text { uninfected (5) }\end{array}$} & $2.01 \pm 0.1$ & $1 \cdot 78 \pm 0 \cdot 1$ & $24 \cdot 2 \pm 1 \cdot 7$ & $63 \cdot 1 \pm 3 \cdot 4$ & $4.46 \pm 0.4$ & $17 \cdot 1 \pm 2 \cdot 2$ & $15 \cdot 4 \pm 0.4$ \\
\hline & $1.94 \pm 0.1$ & $1 \cdot 29 \pm 0 \cdot 1 \ddagger$ & $10 \cdot 3 \pm 0 \cdot 3$ & $49 \cdot 2 \pm 4 \cdot 6$ & $1.00 \pm 0.2$ & $11.4 \pm 0.7$ & $87 \cdot 0 \pm 2 \cdot 7$ \\
\hline & & $1.90 \pm 0.2$ & $6 \cdot 2 \pm 0.3$ & $45 \cdot 2 \pm 2 \cdot 1$ & $0.75 \pm 0.1$ & $9.5 \pm 0.4$ & $\cdots$ \\
\hline
\end{tabular}

\footnotetext{
* Intravenously; with $0.2 \mathrm{mg}$ (wet weight).

$\dagger$ See Materials and methods.

$\ddagger$ Weights of rabbits in this group remained almost stationary up to 40 days after infection, but then fell steadily until death.
} 


\section{TUBERCULOSIS IN LIVER-DAMAGED RABBITS}
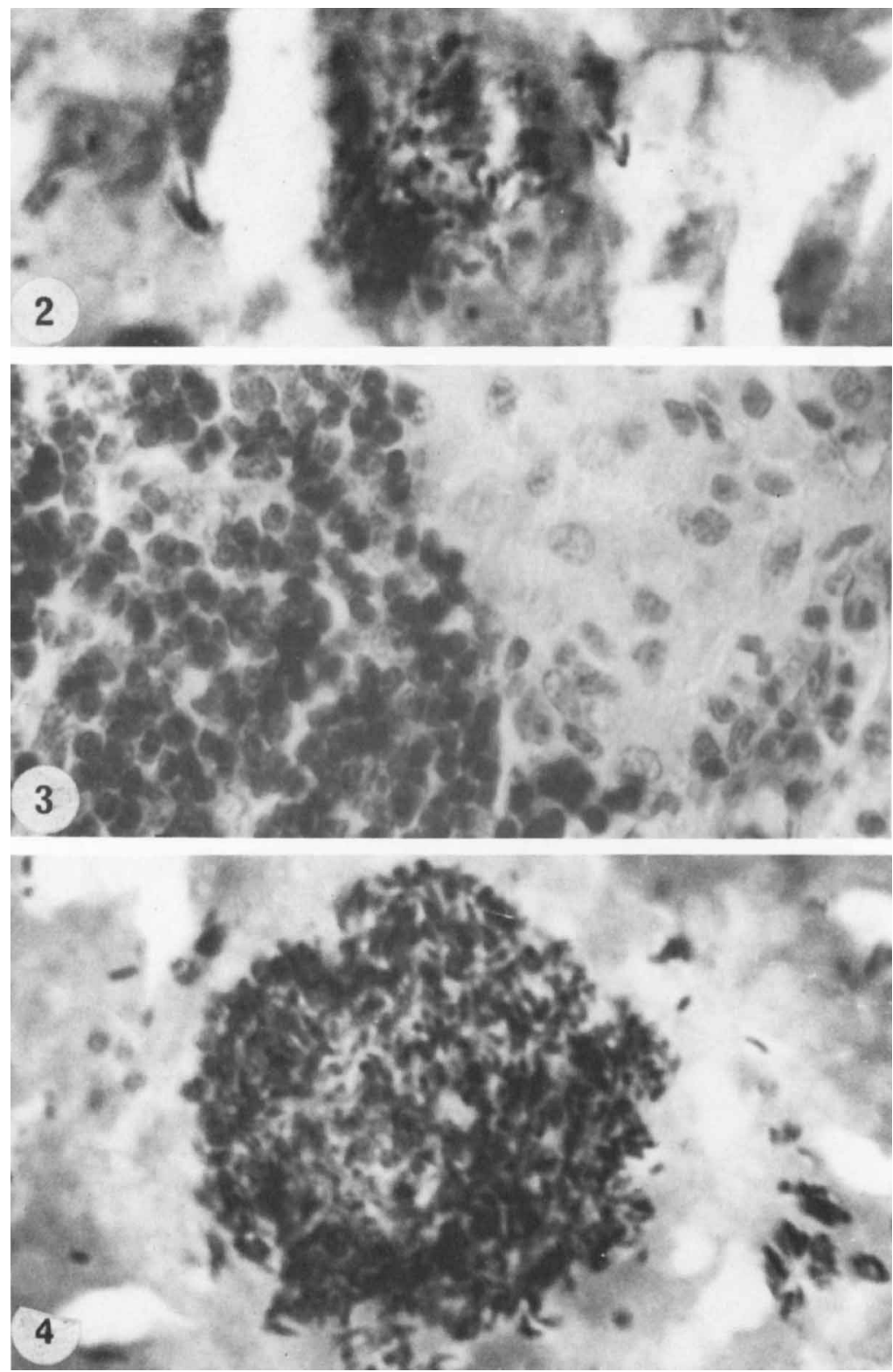

Figs 2-4.-Histopathological changes in the internal organs of rabbits treated with carbon tetrachloride, infected with Mycobacterium avium, and killed 12 days after infection. Fig. 2: clump of acid-fast bacilli in the liver (ZN; $\times 1200)$; fig. 3 : collection of epithelioid cells and lymphocytes in the liver $(\mathrm{H}$ and $\mathrm{E}$; $\times 700)$; fig. 4 : large clump of acid-fast bacilli in the spleen $(\mathrm{ZN} ; \times 1200)$. 
the $\mathrm{CCl}_{4}$ group but scantily positive or negative in the control group, while in animals that died of infection they were uniformly positive in both groups. The colony count from the splenic tissues of animals killed on day 12 was significantly higher in the $\mathrm{CCl}_{4}$ group $\left(1.0 \times 10^{10} / \mathrm{g}\right)$ than in the control group $\left(5 \cdot 0 \times 10^{7} / \mathrm{g}\right)$.

Irrespective of the difference in survival time, the animals of both groups died of progressive infection with similar severity of lesions.

Experiment no. 2. The challenge dose of $M$. avium per rabbit was reduced to $0.2 \mathrm{mg}$ to produce a subacute form of Yersin's disease, because the higher dose of $0.5 \mathrm{mg} / \mathrm{rabbit}$ in the first experiment had resulted in too fulminating a tuberculous infection. The MST of the $\mathrm{CCl}_{4}$ treated animals in the second experiment was $15 \cdot 4 \pm 0.4$ days in comparison with $87 \cdot 0 \pm 2 \cdot 6$ days for the control animals, a significant difference $(\mathrm{p}<0 \cdot 001$ ). (fig. 1). The average body weights of the animals at the time of infection and the time of death in the $\mathrm{CCl}_{4}$-treated group were respectively $2.01 \pm 0.1$ and $1.78 \pm 0.1 \mathrm{~kg}$, whereas they were $1.94 \pm 0.1$ and $1.29 \pm 0.1 \mathrm{~kg}$ in the control group (table I). Two animals from each group were killed on day 16, when half of the animals in the $\mathrm{CCl}_{4}$-treated group had died.

The necropsy findings in animals that had had died, and in those that were killed, showed patterns of lesions that were similar to those seen in experiment no. 1 . The intensity and severity of the lesions were greater in the $\mathrm{CCl}_{4}$-treated group than in the control group. The organ weights at the time of death are shown in table I; those of the $\mathrm{CCl}_{4}$-treated, infected animals were higher than those of the $\mathrm{CCl}_{4}$-untreated, infected animals, which in turn were greater than those of the $\mathrm{CCl}_{4}$-untreated, uninfected animals. The impression smears of the organs from the killed animals were positive in the $\mathrm{CCl}_{4}$ group but negative in the untreated group. The smears of the organs from dead animals were positive in both groups, as in the first experiment. Likewise, the histopathological changes were more severe and the number of AFB in the organs was greater in the $\mathrm{CCl}_{4}$-treated than in the untreated group. The colony-counts per $\mathrm{g}$ of lung, liver, spleen and kidney are shown in table II. The remaining animals of both groups died of progressive disease with the production of Yersin's disease as in the first experiment.

TABLE II

Viable counts of M. avium in the organs of rabbits killed on the 16th day after infection* which had (1) been treated with $\mathrm{CCl}_{4} \dagger$ and (2) not been so treated

\begin{tabular}{l|cccc}
\hline $\begin{array}{c}\text { Experimental } \\
\text { group (number } \\
\text { of animals) }\end{array}$ & \multicolumn{4}{|c}{ Number of colony forming units/g of } \\
\cline { 2 - 5 } lung & liver & spleen & kidney \\
\hline 1. $\mathrm{CCl}_{4}$ treated (2) & $1.3 \times 10^{8}$ & $3.8 \times 10^{7}$ & $3.0 \times 10^{8}$ & $6.0 \times 10^{5}$ \\
2. Untreated (2) & $3.0 \times 10^{3}$ & $2.3 \times 10^{6}$ & $1.1 \times 10^{5}$ & $8.0 \times 10^{3}$ \\
\hline
\end{tabular}

* Intravenously; with $0.2 \mathrm{mg}$ (wet weight).

$\dagger$ See Materials and methods.

\section{DISCUSSION}

In a tropical country such as India, there are a number of common causes of mild grades of liver damage. The incidence of tuberculosis among liver-damaged persons has not been the subject of controlled clinical observation, but case reports indicate the predisposition of these groups to tuberculosis. Therefore, the American Thoracic Society (1975) has recommended BCG vaccination for all socially disadvantaged communities, and for alcoholics and drug addicts.

To investigate experimentally whether mild damage to the liver increases susceptibility to mycobacterial infection, we treated rabbits with $\mathrm{CCl}_{4}$ and observed the progress of infection with $M$. avium in the treated animals and in untreated controls. Our studies with this rabbit model showed that mild liver damage does render the animals more susceptible to infection with 
this mycobacterium than normal animals. This finding provides evidence in support of the clinical impression that liver damage arising from various causes may increase human susceptibility to tuberculosis.

\section{SUMMARY}

A mild grade of liver damage in rabbits was produced by giving 23 subcutaneous injections of carbon tetrachloride $\left(\mathrm{CCl}_{4}\right)$. The $\mathrm{CCl}_{4}$-treated rabbits and untreated controls were subsequently challenged with the mildly virulent strain of Mycobacterium avium Kirschberg (TMC 801). In two successive experiments it has been found that liver damage increased the susceptibility of rabbits to infection with this organism.

We thank Dr Nitya Nand, Director of the Institute for his keen interest in this work. We also thank Mr V. K. Nigam and Mr P. S. Pangati for technical assistance. This is communication no. 2413 of this Institute.

\section{REFERENCES}

AMERICAN Thoracic Society. 1975. BCG vaccines for tuberculosis. Official statement. Am. Rev. resp. Dis., 112, 478.

BAN, B. 1955. Hepatic damage in chronic pulmonary tuberculosis. Am. Rev. Tuberc., 72, 71.

BanerJi, R. N., Lakshmipathy, N., NaG, A. K., Khanna, S. K. and Behari, V. 1968. Non suppurative amoebic hepatitis - a clinical entity and its response to metronidazole therapy. Indian Pract., 21, 749.

Cameron, G. R. and Karunaratne, W. A. E. 1936. Carbon tetrachloride cirrhosis in relation to liver regeneration. J. Path. Bact., 42, 1.

Dayal, R. S., Mathur, G. P., Prasad, R. AND Wahi, P. N. 1968. Indian childhood cirrhosis, clinico-pathological study of 100 cases. Indian Paediat., 5, 17.

Dhatt, P. S., GuPTA, H. L. AND SainI, A. S. 1968. Disaccharide intolerance and Indian childhood cirrhosis. A possible etiological factor. Indian J. med. Res., 56, 39.

GothosKaR, S. B. 1931. Infantile biliary cirrhosis and artificial feeding of infants in India. Indian med. Gaz., 66, 304.

JellifFe, D. B., Bras, G. AND MuKhERJi, K. L. 1957. Veno-occlusive disease of the liver and Indian childhood cirrhosis. Archs Dis. Childh., 32, 369.

Kumar, A. AND DesaI, H. G. 1976. Aetiology of Indian childhood cirrhosis. A new hypothesis. Indian J. med. Sci., 30, 215. 